\title{
Using Technologies as Virtual Environments for Computer Teaching: A Systematic Review
}

\author{
Alex FERNANDO BATISTA, Marcello THIRY, \\ Rafael QUEIROZ GONÇALVES, Anita FERNANDES \\ Applied Computer Science Program, University of Vale do Itajai, Itajai, Brazil \\ e-mail: alex.batista@edu.univali.br, \{thiry,rafaelqg,anita.fernandes\}@univali.br
}

Received: October 2019

\begin{abstract}
This research discusses the use of Augmented Reality, Virtual Reality and Mixed Reality technology applications in the learning process of relevant content to the Computer Science area. This systematic review aims to identify applications that use technologies to represent virtual environments and support the teaching and learning of Computer Science subjects. A protocol was elaborated and executed, resulting in the final selection of 14 papers from four databases, published from 2010 to 2018. The examined papers presented information that categorized technology applications in terms of tools used. Contents addressed to the identification of applied instructional strategies and techniques, and the recognition of effects on the learning process. As a result, we found virtual environments that show potential to teaching basic content in courses related to Computer Science. In addition, the application of virtual environments in this educational scenario has provided positive effects on the learning process, such as increased interactivity, easier content absorption, increased motivation and interest in the subjects, providing greater understanding and improving efficiency in content transmission.
\end{abstract}

Keywords: computer science learning, virtual environment, virtual reality, augmented reality, mixed reality, systematic review.

\section{Introduction}

Educational institutions have been reviewing the use of traditional teaching methods and are focusing on more productive ways to increase students' intellectual experience (Martín-Gutiérrez et al., 2015). Virtual environments have the potential to positively transform the educational system. They allow access to specialized content, to previously limited resources and to physically impossible experiences (Christou, 2010; Greenwald et al., 2017). The application of technologies such as Augmented Reality 
(AR), Virtual Reality (VR) and Mixed Reality (MR) in the reproduction of educational virtual environments, allows the teaching and learning of concepts in several spheres, through interactive, differentiated and facilitated experiences. According to Fernandez (2017), these technologies are focused on improving the results obtained by students in the learning process. Several studies have shown the benefits achieved through using these technologies, such as increased motivation (Ferrer et al., 2013), attention (Ashfaq and Sirshar, 2018; Martín-Gutiérrez et al., 2017), concentration (Alptekin and Temmen, 2018; Chen et al., 2017b) and satisfaction (Chen et al., 2017a).

The research fields applying these technologies are wide, including the teaching of physics (Aveleyra, Raceo and Toba, 2018), chemistry (Yang, Chu and Yang, 2016), biology (Qamari and Ridwan, 2018), mathematics (Radu, Mccarthy and Kao, 2016), music (Serafin et al., 2017), and even medicine (Huang et al., 2017). The benefits and wide application of AR, VR and MR, along with the fast pace of the technological development, have increased the interest in in virtual environment technologies to assist education in the computer teaching (Li et al., 2015).

Teaching subjects in the field of Computer Science is considered difficult such as programming subjects because of their complexity and difficulty of abstraction by students (Alhazbi, 2015; Teng, Chen and Chen, 2018). Alhazbi (2015) also justifies this idea saying that Computer Science courses have a high dropout rate. In order to reverse the problem, this systematic review aims to identify applications that use technologies to represent virtual environments and support the teaching and learning of Computer Science subjects.

The elaboration of this systematic review is part of a broader research, which is the development of a teaching method based on a set of pedagogical activities with the support of a virtual environment. The strategy is focused on improving educational motivation to impact positively in the leaning effectiveness. We also expect to see a significant reduction in the dropout rate of freshman students in a long run. However, before starting this systematic review, we did an informal search of the literature aiming to find tertiary studies about the use of virtual environments in Computer Science learning. No similar studies have been found and the result of our systematic review corroborate the lack of understanding of how virtual environments have been used to support Computer Science education and what impact they have on the students. Therefore, we have been focused on investigate how different applications of AR, VR and MR technologies have been used to support the learning of Computer Science-

To this end, this paper is organized through the systematic review planning, which presents the concepts involved in the research elaboration, the research questions to be answered, the strategy for researching the papers, the criteria for inclusion and exclusion used and the strategy for data extraction. Then, it is presented the conduction of the work execution, that is, how the search strings were elaborated for consultation in the data sources, and the obtained results. Then, the categorizations made to organize the results were presented. And, finally, the analysis performed on the obtained results and the final considerations, which manifest the conclusions of the work and present other scenarios to be explored are displayed. 


\section{Background}

Virtual or digital environments are defined as dynamic scenarios that allow simulating navigation and user interaction in a real projected environment or in a synthetic one (Mello Sobrinho, 2011). According to Sherman and Craig (2003), immersion in these virtual environments occurs by the sensation of being inserted in a space. That immersion can occur mentally, which is when sensation is triggered psychologically and physically involving the notion of physical contact. Milgram and Kishino (1994) have introduced the Reality-Virtuality Continuum shown in Fig. 1. MR systems are those combining real and computer-based information, being the region between the real world and totally virtual environments. It produces a space with the existence of virtual and real elements that can communicate with each other (Hönig et al., 2015).

AR allows the user to broaden the perception of real world through the interaction of virtual objects that contain information, which is not often acquired by the common senses of a human being (Azuma, 1997; Yuen, Yaoyuneyong and Johnson, 2011). It combines real and virtual environments (Milgram and Kishino, 1994; Kesim and Ozarslan, 2012). The main characteristics expected in an AR system are (Azuma et al., 2001):

(i) allow to combine real and virtual objects in a real environment;

(ii) allow real time interaction with the objects; and

(iii) allow alignment between real and virtual objects in the environment.

$\mathrm{VR}$ is identified as driving users to engage in a virtual world through experience. This world can simulate a real environment or a complete new one. These experiences are based on the feeling of being present in an environment (Steuer, 1992; Girvan, 2018). Besides that, Pereira and Piovesan (2010) consider VR as advanced interaction, which offers conditions to experience something that does not exist or is not happening in the real world. According to Xiong, Zhi and Jiang (2018), VR technology has three basic characteristics:

(i) immersion, which is defined when the user has the feeling of being inserted in a virtual environment;

(ii) interactivity, when instruments are available to interact with the virtual environment, such as glasses, gloves and helmets; and

(iii) imagination, which through the rationality and sensitivity gradually achieved in a virtual environment, makes it possible to create more associations about experiences.

VR and AR have similarities between them, such as the interactivity of users with virtual elements and the need to use physical devices to reproduce the environments. Ac-

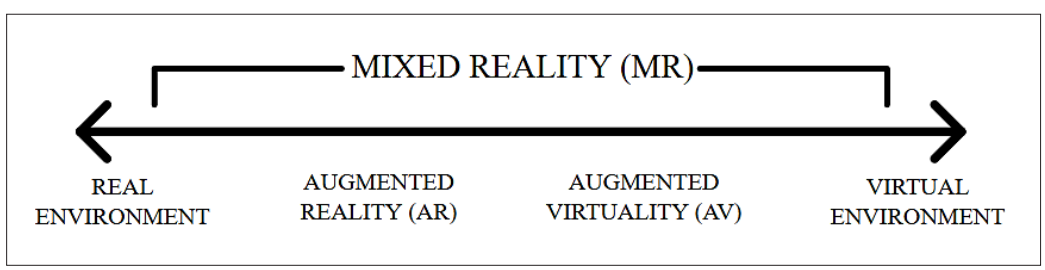

Fig. 1. Reality-Virtuality Continuum (Milgram and Kishino, 1994) 
cording to Kirner and Siscoutto (2007), VR and AR environments amplify users' abilities to evaluate three-dimensional information, as they make space interpretation more flexible and allow the use of interactions in different modes, enabling greater details, better techniques and higher performance.

However, as VR is characterized by being applied in controlled environments, it depends on the use of specific visualization equipment. On the other hand, AR has no space restriction, and includes more accessible equipment, such as mobile phones (Fachinetto, 2013). Ma and Choi (2007) point out that while VR limits the user's physical movements in the real world, AR requires interactive displacement in the real world.

Another difference between VR and AR is in the level of immersion. While VR essentially consists of making the user completely immersed in an artificial world, AR does not omit the notion that the user is inserted in the real world, but augments their reality with virtual elements (Fernandez, 2017; Ma and Choi, 2007). VR completely replaces the real environment with a synthetic one, which makes interaction with the physical world impossible. RA combines the environments, allowing the user interacting with physical and virtual objects (Kiryakova, Angelova and Yordanova, 2018).

\section{Systematic Review Planning}

The elaboration of the systematic review comprises an organization of activities to be performed. According to Brereton et al. (2007), this organization is composed of three main phases:

1. Planning: besides establishing a real utility of systematic review design, this phase comprises the need to define the scope of research by specifying research questions, as well as developing and validating a review protocol.

2. Execution: covers the activities of selecting and identifying relevant research, assessing the quality of the studies found, extracting and monitoring the relevant research data and synthesizing the acquired information.

3. Results presentation: involves the production and evaluation of the systematic review main report.

Then, the elements that make up the systematic literature review protocol are presented. Thus, it is viable to ensure evaluation and reproducibility by other researchers. Also, it is intended to use the protocol as a basis to facilitate future research continuity.

\subsection{Research Questions}

The purpose of this systematic review is to investigate tools that make use of technologies that reproduce virtual environments to teach relevant concepts to Computer Science area. Thus, the primary research questions seek to answer how these tools are character- 
ized, which instructional processes they present, and what effects on the learning process are. To assist in the resolution of the questions, secondary questions were elaborated. Therefore, this study commits itself to fulfill the objective by solving the following questions (QP - main and QS - secondary):

- QP01: How are AR, VR, or MR-based learning applications for Computer Science teaching characterized?

QS01.01: What are the contents covered?

Q QS01.02: What technologies are employed (tools, frameworks, libraries)?

Q QS01.03: What types of application are used?

QS01.04: What are the characteristics of AR, VR and MR technologies?

- QP02: What are the processes found in learning classes? AR, VR or MR for the teaching of Computer Science?

QS02.01: What are the instructional strategies?

QSS02.02: What are the instructional techniques?

- QP03: What are the learning effects of using AR, VR, or MR technologies in the teaching of Computer Science?

Q QS03.01: What techniques have been employed to evaluate the learning effect?

QS03.02: What are the learning outcomes found?

From this, a study was performed to define the terms to be used, and the strategy considered to find the papers in the data sources.

\subsection{Strategy Used for Primary Studies Research}

The research was restricted to electronic databases, involving conference proceedings and journals. We use IEEE Explore ${ }^{1}$, ACM Digital Library ${ }^{2}$, Springer Link ${ }^{3}$ and ERIC ${ }^{4}$ data sources. We chose these sources because they offered relevant publications about the subject of research and allow retrieving the full text of the paper more easily. Also, the period considered in the research of published papers was defined between January 2010 and December 2018, since, in similar studies, the research interval is set between 6 (six) and 7 (seven) years. Moreover, in the same similar studies, we found no applications prior to 2010, which meet the selection criteria of this systematic review.

For the search terms, we used English language. The terms used in the research refer to the application of technologies that reproduce virtual environments, such as AR, VR or MR for the teaching of Computer Science in various areas of knowledge.

The search string was designed from combinations of key terms that best fit the research objective, which resulted in: "(augmented reality OR virtual reality OR mixed reality) AND (teaching OR learning OR mentoring) AND (computer science OR programming OR software engineering OR data structure OR computer network OR operating system

\footnotetext{
${ }^{1}$ http://ieeexplore.ieee.org/

2 https://dl.acm.org/

${ }^{3}$ https://link.springer.com/

${ }^{4}$ https://eric.ed.gov/
} 


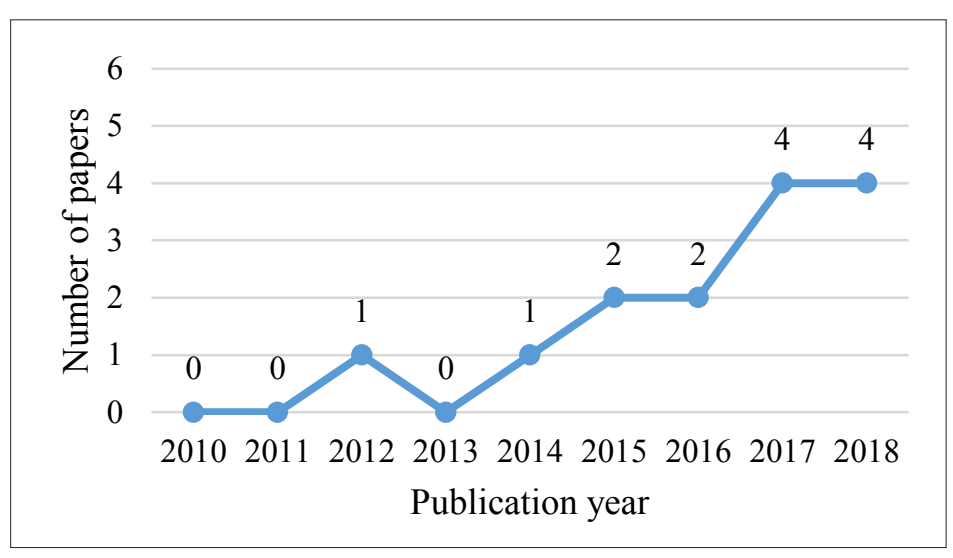

Fig. 2. Number of papers by year of publication.

OR artificial intelligence OR computer architecture OR theory of computation OR database OR human computer interaction OR algorithm OR formal languages)". Although the number of combinations is considered high, the understanding is simple because it is based on identifying the application of a technology in some area of knowledge.

The number of published papers presenting the use of AR, VR and MR technologies in the educational context in the Computer Science area has been growing in recent years, as can be seen in Fig. 2.

Fig. 2 shows that there has been an increase in paper publishing and solution development in recent years. This increase can be observed mainly from $2014(n=1)$ on. The last two years (2017 and 2018) is the period where there has been a higher number of occurrences $(n=4)$.

\subsection{Study Selection Criteria and Procedures}

The criteria for inclusion of the studies were:

- Documents must be available on the web.

- Papers published from January 2010 until December 2018.

- Papers filtered by search phrase considering title, abstract, and keywords.

- Papers written in the English language.

- Peer reviewed papers.

In addition to papers that do not meet the inclusion criteria, there are those that:

- Presented the application for professional or industry use.

- Did not demonstrate the use of one of AR, VR or MR technologies as a central element.

- Did not present content related to the teaching of Computer Science.

- Did not present evaluation of the learning effect, either qualitative or quantitative.

- Were categorized as summaries or extended summaries. 
The procedures necessary for the studies selection were defined in the following order:

1. The researcher performs the search on the selected data sources by applying the string adapted according to the search engine.

2. Papers are selected according to the circumstances defined in the inclusion and exclusion criteria. This verification happens according to some characteristics of the research and occurs by reading papers abstracts.

3. Included papers are documented and displayed in a table for data extraction.

Papers included as a result of initial research are reviewed by only one researcher.

\subsection{Data Extraction Strategy}

For each paper selected, according to the inclusion criteria, basic information was extracted for references, such as authors name, paper title and year of publication. In addition to answering QP01, QS01.01, QS01.02, QS01.03 and QS01.04, which characterize applications in the educational context of Computer Science, the following features were extracted:

- Technology (AR/VR/MR): identification of technologies used to characterize virtual environments. These technologies are in agreement with the proposal of this research, which is analysis of the AR, VR and MR technologies.

- Tools Used (Tool Name): indicates the tools used in the design and presentation of the virtual environment. It can be a framework or library, such as Unity3D and Vuforia. No tool constraints were defined for this research because the goal is to investigate what is being used the most.

- Visual resources (images/audios/videos/animations/3D elements): highlights the visual resources used to represent the virtual environment. Visual resource means any element that interacts with the user, such as 3D elements.

- Covered content (type of content addressed): points the teaching content covered. This content is restricted according to the proposal of this research, namely the teaching of Computer Science.

- Application Type (game/simulator): indicates the form of user interaction with the virtual environment, such as a case simulation.

- Main feature of technology (characterization of technology): highlights the main feature of technology employed in the virtual environment, for example, identify if the environment is immersive, or uses markers.

In order to answer QP02, QS02.01 and QS02.02, which determine instructional processes, the following information was extracted:

- Instructional strategies (presentation/discovery/collaborative): characterizes the strategies used to provide information and how it is absorbed by students interacting with the application.

- Instructional techniques (investigation/observation/game): points out the techniques used, which determine how activities are performed to achieve the objectives. 
Finally, to answer QP03, QS03.01 and QS03.02, which is intended to collect learning outcomes and effects, the following information was analyzed:

- Purpose of the research (the reason for the application): what is intended to be achieved by employing technology in a virtual environment for the learning process. It refers to the investigation of the behavior of technology; teaching, aid, facility, comparison, etc.

- Learning outcomes (learning effects): this criterion identifies learning effects observed or reported by students as applied to the survey, for example increased motivation, increased satisfaction.

- Results evaluation method (qualitative / quantitative / experimental / mixed): identifies whether statistical means were used to evaluate the results, or was subjective, through interviews with the evaluators. Also, if more than one means of evaluation was used.

- Course or subject (course or subject name): this criterion identifies the area of Computer Science in which the research was applied.

- Number of people who rated (number of reviewers): indicates the number of individuals who rated the tool. It is not restricted to students only, but also to educators.

- Activities duration (time or period): this criterion seeks to know the average time or period of application of the work.

\section{Systematic Review Conduction}

In the planning of the systematic review, the first execution of the string in the search engines occurred in October 2018, having as inclusion criteria only papers published in the period 2010-2018, returned approximately 6,000 publications. Given this, it was noted the need for improvement in the construction of the search string, in order to insert a maximum number of inclusion and exclusion criteria. In addition, data sources have their own search engines, so the strings were adapted respecting the particularities and limitations presented.

The adapted strings were executed on April 2019. After that, the collection and analysis phase of the search works started, with 677 returning papers. Results were distributed by data source, as shown in Table 1 . The percentage represents the amount of papers selected in each data source related to the total of papers returned in all data sources (677).

Table 1

Amount of papers selected applying the inclusion and exclusion criteria

\begin{tabular}{lllcrc}
\hline Analysis Procedure & IEEE Explore & $\begin{array}{l}\text { ACM Digital } \\
\text { Library }\end{array}$ & ERIC & SpringerLink & Total \\
\hline Search string adapted & 94 & 377 & 14 & 192 & $\mathbf{6 7 7}$ \\
$\begin{array}{l}\text { Selection using inclusion } \\
\text { and exclusion criteria }\end{array}$ & 10 & 3 & 1 & 0 & $\mathbf{1 4}$ \\
\hline
\end{tabular}




\subsection{Results Obtained from the Implementation of the Review}

Table 2 lists the selected papers, accompanied by the identification, their references, data source from which the paper was taken, and a brief description of the paper.

Table 2

Selected papers

\begin{tabular}{llll}
\hline ID & Reference & Source & Abstract \\
\hline S01 (Chandramouli, & IEEE & The paper presents a virtual environment using VR technology to \\
$\begin{array}{l}\text { Zahraee and Winer, } \\
\text { 2014) }\end{array}$ & & $\begin{array}{l}\text { Explore } \\
\text { teach programming concepts to students facing learning disabilities. } \\
\text { the motivational factor. This interactive environment allows students } \\
\text { to explore and understand programming concepts through practical } \\
\text { examples. }\end{array}$
\end{tabular}

S02 (Teng and Chen, 2012)

S03 (Grivokostopoulou, Perikos and Hatzilygeroudis, 2016)

S04 (Mesía, Sanz and Gorga, 2016)

S05 (Dass et al., 2018)

S06 (Vincur et al., 2017)

S07 (Bujdoso, Novac and Szimkovics, 2017)

S08 (Teng, Chen and Chen, 2018)
IEEE The authors of this paper developed an AR environment to teach Explore basic OpenGL programming concepts such as scaling, rotating and translating through visualization and interaction with $3 \mathrm{D}$ models and markers. The behavior of the virtual environment is the visualization of a $3 \mathrm{D}$ model that is interpreted through the interaction with algorithms that are inserted in markers in a QR code format. The environment allows students to be able to create their own markers to test OpenGL programming code.

IEEE This paper presents an environment based on VR technology, to assist Explore the teaching of search algorithms, which are considered fundamental in Computer Science domain. The goal is to facilitate understanding of abstract concepts through concrete experiences and procedures. It describes the use of gamification concepts to motivate students.

IEEE Describes collaborative experiences using technologies such as AR to Explore teach control structures in early programming courses. The objective is to evaluate if the tool motivates students to seek knowledge.

ACM The paper presents an investigation whether the use of AR technology Digital can enhance programming learning. Twelve participants were evaluated Library using technologies such as Microsoft HoloLeans and a mobile application using ARKit on the iPhone. The results presented indicate that AR technology drives this initial learning.

ACM This paper shows an immersive environment utilizing VR that enables Digital students to solve programming challenges like those available on the Library code.org online platform. The goal is getting students to solve algorithms using virtualized cubes that represent programming instructions.

IEEE The paper shows a collaborative and cooperative tool that uses VR Explore technology to leverage important skills such as creativity, invention and innovation of programmers within the Computer Science course.

ERIC Faced with the difficulty found by students in learning a programming language, especially for 3D applications, an immersive and interactive virtual environment for programming teaching focused on 3D applications was developed. To validate the application, an experiment was conducted with a group of 34 students. 
Table 2 - continued from previous page

\begin{tabular}{|c|c|c|c|}
\hline ID & Reference & Source & Abstract \\
\hline S09 & $\begin{array}{l}\text { (Hsu, Chen and } \\
\mathrm{Wu}, 2015)\end{array}$ & $\begin{array}{l}\text { IEEE } \\
\text { Explore }\end{array}$ & $\begin{array}{l}\text { The paper presents an investigation about the effects that a tool, which } \\
\text { uses AR techniques, teaches about the history of Computer Science. The } \\
\text { goal is that the student, when interested in historical photos and pointing } \\
\text { to the photo (marker), trigger a video with explanation about the content. } \\
\text { From an assessment submitted to a group of students, it was observed } \\
\text { that the tool supports students in the acquisition of knowledge. }\end{array}$ \\
\hline $\mathrm{S} 10$ & (Li et al., 2015) & $\begin{array}{l}\text { IEEE } \\
\text { Explore }\end{array}$ & $\begin{array}{l}\text { The paper presents a series of } 18 \text { experiments using VR technology, with } \\
\text { the goal to aid in the teaching of concepts and skills for the Introduction } \\
\text { to Computer Science discipline. Among the contents covered are: } \\
\text { Turing machine and computer assembly; information representation and } \\
\text { calculation; information coding and processing; computer instruction } \\
\text { execution; and process management and virtual machine. }\end{array}$ \\
\hline S11 & $\begin{array}{l}\text { (Oberhauser and } \\
\text { Lecon, 2017) }\end{array}$ & $\begin{array}{l}\text { ACM } \\
\text { Digital } \\
\text { Library }\end{array}$ & $\begin{array}{l}\text { The paper describes and evaluates the use of a virtual environment using } \\
\text { VR technology to visualize data structures in order to facilitate learning. } \\
\text { Results are compared to a non-virtual application. }\end{array}$ \\
\hline $\mathrm{S} 12$ & $\begin{array}{l}\text { (Stigall and } \\
\text { Sharma, 2017) }\end{array}$ & $\begin{array}{l}\text { IEEE } \\
\text { Explore }\end{array}$ & $\begin{array}{l}\text { The paper describes the development of two game modules to teach } \\
\text { object-oriented programming (OOP) and binary search concepts using } \\
\text { VR technology. }\end{array}$ \\
\hline $\mathrm{S} 13$ & $\begin{array}{l}\text { (Nicola, Stoicu- } \\
\text { Tivadar and } \\
\text { Patrascoiu, 2018) }\end{array}$ & $\begin{array}{l}\text { IEEE } \\
\text { Explore }\end{array}$ & $\begin{array}{l}\text { The paper presents the development of an application that uses VR to } \\
\text { help in the understanding of sorting algorithms. }\end{array}$ \\
\hline S14 & $\begin{array}{l}\text { (Visoottiviseth } \\
\text { et al., 2018) }\end{array}$ & $\begin{array}{l}\text { IEEE } \\
\text { Explore }\end{array}$ & $\begin{array}{l}\text { The paper presents the development of a game that uses VR to facilitate } \\
\text { and assist in the understanding of concepts related to network security in } \\
\text { the Computer Science course. With the results it was possible to notice } \\
\text { increase in the ease of understanding the content. In addition, there was } \\
\text { an increase in the motivation of students seeking knowledge. }\end{array}$ \\
\hline
\end{tabular}

\section{Categorization of Processes Found}

Once the results of the systematic execution were found, the extracted data were classified in order to analyze and answer the research questions more easily.

Table 3 was organized according to the criteria defined to respond to QP01, QS01.01, QS01.02, QS01.03 and QS01.04, which were intended to identify which technology is most used to reproduce a virtual environment.

Table 3

Criteria used to answer QP01 and its secondary questions

\begin{tabular}{lllllll}
\hline ID & $\begin{array}{l}\text { Tech- } \\
\text { nology }\end{array}$ & Tools Used & Visual Resources & Content Covered & $\begin{array}{l}\text { Application } \\
\text { Type }\end{array}$ & $\begin{array}{l}\text { Main Feature of } \\
\text { Technology }\end{array}$ \\
\hline S01 & VR & Undefined & 3D Elements & Programming Logic & Simulator & Immersive VR \\
S02 & AR & ARToolKit & 3D Elements & OpenGL Programming & Simulator & AR with Makers \\
\hline
\end{tabular}


Table 3 - continued from previous page

\begin{tabular}{|c|c|c|c|c|c|c|}
\hline S03 & VR & $\begin{array}{l}\text { Open } \\
\text { Simulator }\end{array}$ & $\begin{array}{l}\text { Images and 3D } \\
\text { Elements }\end{array}$ & $\begin{array}{l}\text { Search Algorithms and } \\
\text { Artificial Intelligence }\end{array}$ & Game & $\begin{array}{l}\text { Non-Immersive } \\
\text { VR }\end{array}$ \\
\hline S04 & AR & $\begin{array}{l}\text { FLARMa- } \\
\text { nager }\end{array}$ & 3D Elements & Flux Control & Simulator & AR with Makers \\
\hline S05 & AR & $\begin{array}{l}\text { Unity3D } \\
\text { and ARKit }\end{array}$ & $\begin{array}{l}\text { Images, videos and } \\
\text { 3D Elements }\end{array}$ & Programming Logic & Simulator & AR with Makers \\
\hline S06 & VR & Unity3D & 3D Elements & Algorithms & Game & Immersive VR \\
\hline S07 & VR & $\begin{array}{l}\text { VirCA and } \\
\text { MaxWhere }\end{array}$ & $\begin{array}{l}\text { Images, audio and } \\
\text { 3D Elements }\end{array}$ & Computational Thinking & Simulator & Immersive VR \\
\hline S08 & AR & OpenGL & 3D Elements & OpenGL Programming & Simulator & AR with Makers \\
\hline S09 & AR & Aurasma & Videos & $\begin{array}{l}\text { Computer Science } \\
\text { History }\end{array}$ & Simulator & AR with Makers \\
\hline S10 & VR & Undefined & $\begin{array}{l}\text { Images and 3D } \\
\text { Elements }\end{array}$ & $\begin{array}{l}\text { Introduction to Computer } \\
\text { Science }\end{array}$ & Simulator & $\begin{array}{l}\text { Non-Immersive } \\
\text { VR }\end{array}$ \\
\hline $\mathrm{S} 11$ & VR & Unity3D & $\begin{array}{l}\text { Images, animations } \\
\text { and 3D Elements }\end{array}$ & Code Structures & Simulator & Immersive VR \\
\hline $\mathrm{S} 12$ & VR & $\begin{array}{l}\text { Vizard VR } \\
\text { Toolkit }\end{array}$ & 3D Elements & $\begin{array}{l}\text { Object Orientation and } \\
\text { Binary Search }\end{array}$ & Game & $\begin{array}{l}\text { Non-Immersive } \\
\text { VR }\end{array}$ \\
\hline $\mathrm{S} 13$ & VR & Unity3D & 3D Elements & Algorithms & Game & Immersive VR \\
\hline S14 & VR & Unity3D & $\begin{array}{l}\text { Images, animations } \\
\text { and 3D Elements }\end{array}$ & Network Secutiry & Game & Immersive VR \\
\hline
\end{tabular}

Table 4 presents the criteria used to identify the instructional processes characterized in the applications, which respond to QP02, QS02.01 and QS02.02.

Table 4

Criteria used to answer QP02 and its secondary questions

\begin{tabular}{lll}
\hline ID & Instructional Strategies & Instructional Techniques \\
\hline S01 & Discovery & Investigation \\
S02 & Discovery & Investigation \\
S03 & Discovery & Investigation and Game \\
S04 & Discovery & Investigation \\
S05 & Discovery & Investigation \\
S06 & Discovery & Investigation and Game \\
S07 & Collaborative & Investigation \\
S08 & Presentation & Observation \\
S09 & Presentation & Investigation \\
S10 & Discovery & Investigation \\
S11 & Discovery & Investigation \\
S12 & Discovery & Investigation \\
S13 & Discovery & Investigation \\
S14 & Discovery & Investigation and Game \\
\hline
\end{tabular}


In order to understand the purpose of applying the selected works and to investigate the learning effects of the studies, as questioned in QP03, QS03.01 and QS03.02, the defined criteria are presented in Table 5.

Table 5

Criteria used to answer QP03 and secondary

\begin{tabular}{|c|c|c|c|c|c|c|}
\hline ID & Research Purpose & $\begin{array}{l}\text { Learning } \\
\text { Outcomes }\end{array}$ & $\begin{array}{l}\text { Results } \\
\text { Evaluation } \\
\text { Method }\end{array}$ & $\begin{array}{l}\text { Course or } \\
\text { Subject }\end{array}$ & $\begin{array}{l}\text { Number } \\
\text { of People } \\
\text { Who Rated }\end{array}$ & $\begin{array}{l}\text { Activity } \\
\text { Duration }\end{array}$ \\
\hline S01 & $\begin{array}{l}\text { Investigate the effect of } \\
\text { using VR technology on } \\
\text { the learning process }\end{array}$ & $\begin{array}{l}\text { Exploration } \\
\text { Involvement } \\
\text { Understanding } \\
\text { Skills }\end{array}$ & Undefined & $\begin{array}{l}\text { Programming } \\
\text { Teaching in } \\
\text { Engineering } \\
\text { Course }\end{array}$ & Undefined & Undefined \\
\hline S02 & $\begin{array}{l}\text { Assist and facilitate } \\
\text { OpenGL programming } \\
\text { teaching }\end{array}$ & No results & Undefined & $\begin{array}{l}\text { OpenGL } \\
\text { Programming }\end{array}$ & Undefined & Undefined \\
\hline S03 & $\begin{array}{l}\text { Assist involved in the } \\
\text { learning process about } \\
\text { search algorithms }\end{array}$ & $\begin{array}{l}\text { Motivation } \\
\text { Satisfaction } \\
\text { Commitment } \\
\text { Interest } \\
\text { Recognition }\end{array}$ & Quantitative & $\begin{array}{l}\text { Artificial } \\
\text { Intelligence }\end{array}$ & 44 students & 1 study \\
\hline S04 & $\begin{array}{l}\text { Teach basic programming } \\
\text { concepts }\end{array}$ & $\begin{array}{l}\text { Understanding } \\
\text { Motivation } \\
\text { Interactivity } \\
\text { Satisfaction }\end{array}$ & Mixed & $\begin{array}{l}\text { Programming } \\
\text { Teaching in } \\
\text { Computer } \\
\text { Science }\end{array}$ & 54 students & $\begin{array}{l}\text { Four } \\
\text { 4-minute } \\
\text { experiments }\end{array}$ \\
\hline S05 & $\begin{array}{l}\text { Investigate the use of } \\
\text { AR technology in pro- } \\
\text { gramming teaching and } \\
\text { comparison with other } \\
\text { technology }\end{array}$ & $\begin{array}{l}\text { Facility } \\
\text { Skills }\end{array}$ & Mixed & Undefined & 12 students & 12 sessions \\
\hline S06 & $\begin{array}{l}\text { Assist in teaching } \\
\text { programming logic }\end{array}$ & Facility & Qualitative & Undefined & 18 students & 2 studies \\
\hline S07 & $\begin{array}{l}\text { Introduce teaching } \\
\text { method to increase } \\
\text { creativity }\end{array}$ & $\begin{array}{l}\text { Creativity } \\
\text { Motivation } \\
\text { Ability to inno- } \\
\text { vate } \\
\text { Troubleshooting }\end{array}$ & Experimental & $\begin{array}{l}\text { Information } \\
\text { Technology }\end{array}$ & Undefined & Undefined \\
\hline S08 & $\begin{array}{l}\text { Investigate the influence } \\
\text { of AR technology in } \\
\text { teaching a programming } \\
\text { language }\end{array}$ & $\begin{array}{l}\text { Efficiency } \\
\text { Facility }\end{array}$ & Mixed & $\begin{array}{l}\text { Introduction } \\
\text { to } \\
\text { programming } \\
\text { language }\end{array}$ & 34 students & $\begin{array}{l}\text { 25-minute } \\
\text { sessions }\end{array}$ \\
\hline S09 & $\begin{array}{l}\text { Investigate the effect of } \\
\text { using AR technology } \\
\text { on teaching computer } \\
\text { history }\end{array}$ & $\begin{array}{l}\text { Facility } \\
\text { Interest }\end{array}$ & Qualitative & $\begin{array}{l}\text { Computer } \\
\text { Science }\end{array}$ & 84 students & 4 weeks \\
\hline
\end{tabular}


Table 5 - continued from previous page

\begin{tabular}{|c|c|c|c|c|c|c|}
\hline ID & Research Purpose & $\begin{array}{l}\text { Learning } \\
\text { Outcomes }\end{array}$ & $\begin{array}{l}\text { Results } \\
\text { Evaluation } \\
\text { Method }\end{array}$ & $\begin{array}{l}\text { Course or } \\
\text { Subject }\end{array}$ & $\begin{array}{l}\text { Number } \\
\text { of People } \\
\text { Who Rated }\end{array}$ & $\begin{array}{l}\text { Activity } \\
\text { Duration }\end{array}$ \\
\hline S10 & $\begin{array}{l}\text { Assist the process of } \\
\text { learning concepts of } \\
\text { Introduction to Computer } \\
\text { Science }\end{array}$ & $\begin{array}{l}\text { Students: } \\
\text { Motivation } \\
\text { Interest } \\
\text { Understanding } \\
\text { Satisfaction } \\
\text { Teamwork } \\
\text { Effectiveness } \\
\text { Discussion } \\
\text { Interactivity } \\
\text { Teachers: } \\
\text { Efficient } \\
\text { Effectiveness } \\
\text { Interactivity } \\
\text { Fa-cility }\end{array}$ & Qualitative & $\begin{array}{l}\text { Introduction } \\
\text { to Computer } \\
\text { Science }\end{array}$ & $\begin{array}{l}1.158 \\
\text { students } \\
\text { and } 40 \\
\text { teachers }\end{array}$ & Undefined \\
\hline S11 & $\begin{array}{l}\text { Present an environment } \\
\text { for easy viewing of } \\
\text { different code structures }\end{array}$ & $\begin{array}{l}\text { Facility } \\
\text { Efficiency } \\
\text { Motivation }\end{array}$ & Experimental & Undefined & 12 students & Undefined \\
\hline $\mathrm{S} 12$ & $\begin{array}{l}\text { Facilitate the learning } \\
\text { process of object-oriented } \\
\text { programming and binary } \\
\text { searching }\end{array}$ & $\begin{array}{l}\text { Facility } \\
\text { Absorption }\end{array}$ & Qualitative & $\begin{array}{l}\text { Introduction } \\
\text { to Computer } \\
\text { Science }\end{array}$ & 20 students & 2 studies \\
\hline S13 & $\begin{array}{l}\text { Facilitate the learning } \\
\text { process of sorting } \\
\text { algorithms }\end{array}$ & $\begin{array}{l}\text { Facility } \\
\text { Interactivity }\end{array}$ & Quantitative & $\begin{array}{l}\text { Automation } \\
\text { and } \\
\text { computers }\end{array}$ & 30 students & 10 minutes \\
\hline S14 & $\begin{array}{l}\text { Facilitate understanding } \\
\text { of network security }\end{array}$ & $\begin{array}{l}\text { Facility } \\
\text { Understanding } \\
\text { Motivation } \\
\text { Interest }\end{array}$ & Quantitative & $\begin{array}{l}\text { Network } \\
\text { Security }\end{array}$ & 33 students & Undefined \\
\hline
\end{tabular}

\section{Discussion}

In order to understand the application of technologies that allow reproducing a virtual environment, this systematic review was proposed. It searched for papers that apply technologies to assist in the process of learning Computer Science related content. During the execution, 677 papers were found, using the search string adapted to the data sources. After the refinement of the papers, based on the criteria defined for inclusion and exclusion, 14 papers were extracted.

\section{How are AR, VR, or MR-based learning applications for Computer Science teaching characterized?}

One of the main highlights of the systematic review was that it was not possible to find papers pointing to the use of MR technology for teaching Computer Science. On the 
other hand, during the results selection phase, using the inclusion and exclusion criteria, we noticed works in progress, but that have not yet been applied and evaluated, so they did not meet the established criteria. From the results found, we identified five (35.71\%) papers that used AR technology and nine (64.29\%) that used VR technology.

With the collected results, we observe that the learning applications based on AR and VR technologies, include diverse contents in the teaching of Computer Science. These contents range from initial course levels, such as teaching Algorithms (S01, S04, S06 and S13) and Introduction to Computer Science (S09 and S10), to more advanced levels such as OpenGL Programming (S02 and S08), Search Algorithms (S03 and S12), Artificial Intelligence (S03) and Network Security (S14).

The results collected were categorized as games or simulators. Games have been defined as applications that include some process of rewarding the student using it. On the other hand, simulators were defined as applications that became more concerned with projecting a real learning situation. Still, the analyzed virtual environments used software, frameworks and libraries to make the teaching environment available. Tools such as Unity3D (S05, S06, S11, S13 and S14), Aurasma (S09) and OpenGL (S08) have been identified that provide platforms for AR and VR application development.

Finally, the main characteristics observed in AR and VR technologies in virtual environments are that when using VR, the proposal is to build totally immersive environments for students. Only three of the selected papers were categorized as non-immersive ( $\mathrm{S} 03$, $\mathrm{S} 10$ and S12). From the results that use AR technology (S02, S04, S05, S08 and S09), all have the characteristic of using markers to provide interaction to students. We did not find any applications with the feature of using geolocation for student interaction.

\section{What instructional processes are found in AR, VR or MR-based learning applications for Computer Science teaching?}

As defined by Akdeniz (2016), instruction is a complete process applied to the development of target learning, aimed at students. In some studies, instructional strategies are classified according to how the process works, how information is produced, and how it is absorbed by students, while in others, these strategies are classified based on instructional models (Akdeniz, 2016).

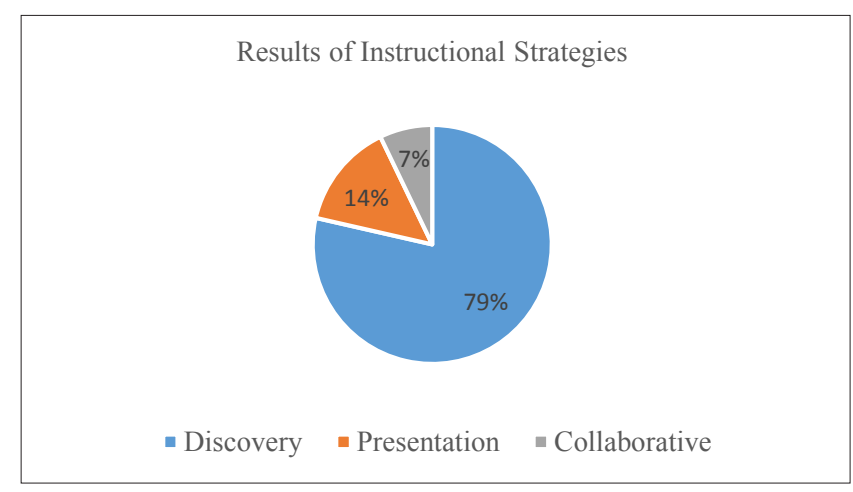

Fig. 3. Distribution of results by instructional strategies. 


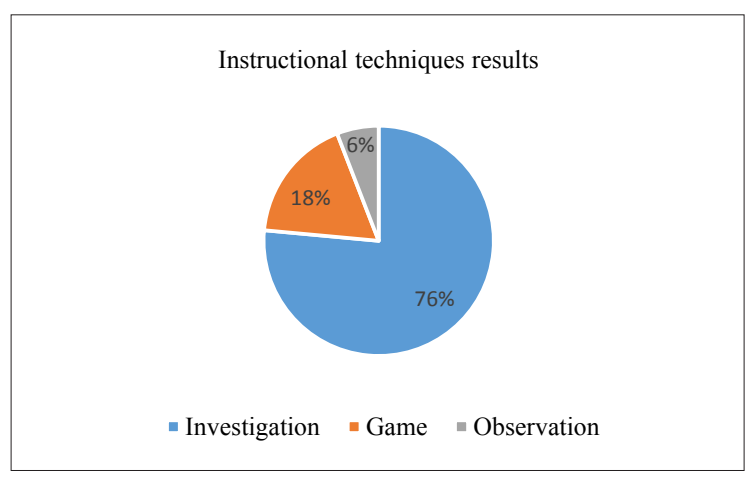

Fig. 4. Distribution of results by instructional techniques.

The instructional strategies were defined based on the results found and are categorized as: discovery; presentation; and collaborative (Fig. 3).

Fig. 3 illustrates the distribution results found by instructional strategy. The discovery, which represents the concept of the application providing students with the construction of their own knowledge, was observed in 11 papers $(79 \%)$. The presentation, in which the content is demonstrated without the need of investigation, represents two papers (14\%) of the research. And finally, the collaborative strategy, which encourages students to play a cooperative role in knowledge building, was found in only one paper (7\%).

Instructional techniques are defined as methods that contain good practices applied in conjunction with instructional strategies to use resources that enable the student to acquire knowledge effectively (Sottilare, Defalco and Connor, 2014).

The instructional techniques found in the results were categorized as: investigation; game; and observation (Fig. 4).

Fig. 4 presents the distribution of the results found by instructional technique. The research, which represents 13 resulting papers $(76 \%)$, proposes that students search the content approached to acquire knowledge. The game technique commits itself to offering the very elements of a game, such as reward for completed task, and depicts three papers (18\%) of the selected results. Finally, observation indicates that students will gain knowledge by observing content presented to them. This technique was found in one paper $(6 \%)$.

\section{What are the learning effects of using AR, VR, or MR technologies in Computer Science teaching?}

To evaluate the environments proposed in the selected papers, research methods were used (Fig. 5).

Fig. 5 presents the research methods used to evaluate the results. The qualitative method (29\%) was the most used, followed by the quantitative one $(22 \%)$. Papers that applied more than one research method represent $21 \%$, while papers that used the experimental method and those that were not defined represent $14 \%$ each.

During the learning effects analysis process in the selected papers, it was observed that the applications have multiple positive effects, which were observed by students and teachers in different scenarios. 


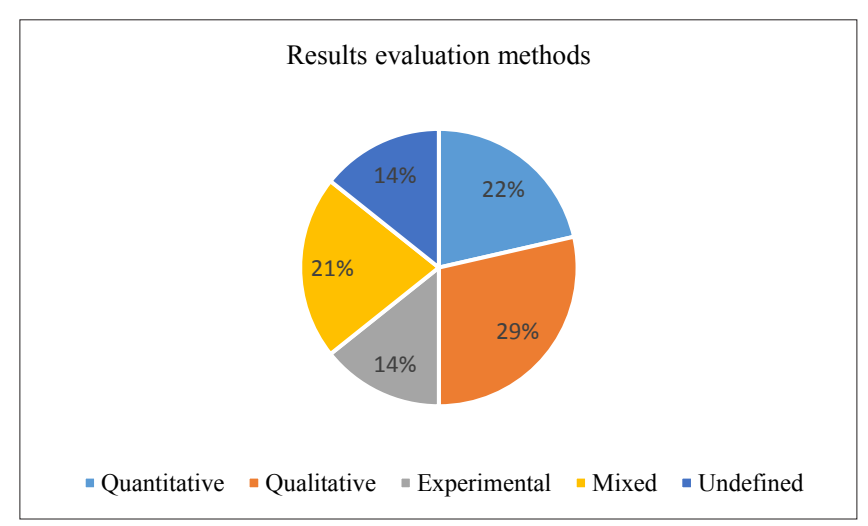

Fig. 5. Distribution of papers by learning effects.

Some papers had learning effects observed only once $(n=1)$, such as increased exploitability (S01), greater engagement with content (S01), increased engagement (S03), greater recognition of the importance of content (S03), increased creativity (S07), greater ability to innovate (S07), easier problem solving (S07), higher content absorption rate (S12), and increased ability to do teamwork (S10) ). In Fig. 6 are the most common effects among papers.

Fig. 6 shows the main effects observed in the selected papers. The most frequent positive effect on work is the ease students have with the learning process $(n=9)$. Then, virtual environments provided increased motivation for students to learn content $(n=6)$. Moreover, there was an increase in students' interest $(n=4)$, and thus a greater understanding of the content $(n=4)$. Finally, other positive effects on learning were found more than once in the selected results, such as higher student satisfaction $(n=3)$, increased interactivity of subjects $(n=3)$, greater efficiency in knowledge transmission $(\mathrm{n}=3)$ and increased student skills $(\mathrm{n}=2)$.

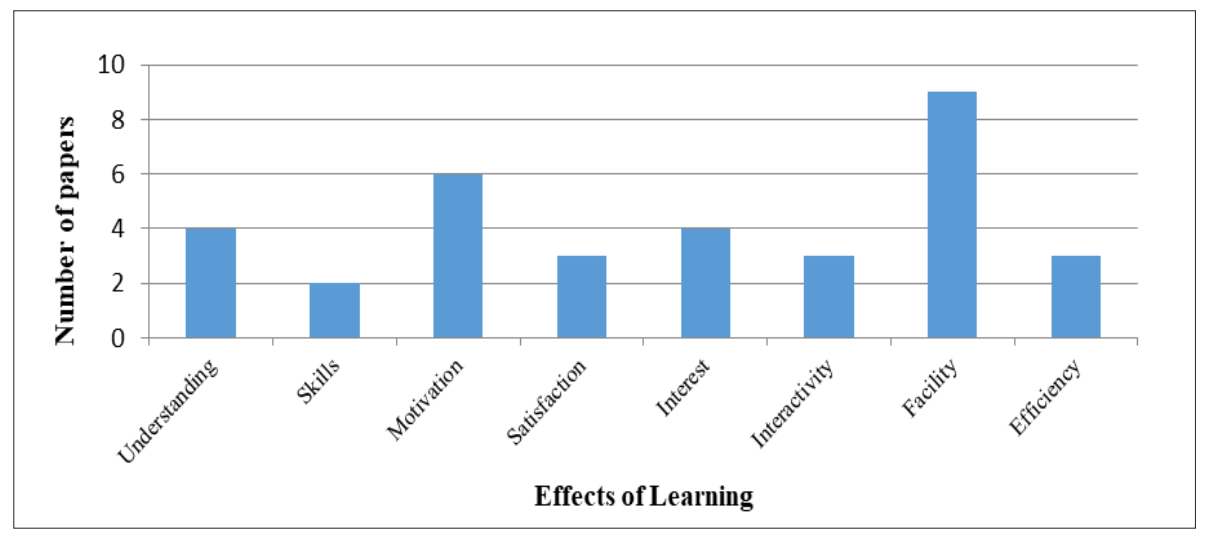

Fig. 6. Number of papers by learning effect. 


\section{Implications for Educators}

There is still not a clear vision of how to integrate technologies as AR and VR in a stable way into an educational process (Martín-Gutiérrez et al., 2017). There are difficulties like the resistance of traditional learning environments to integrate educational innovations, the opposition of teachers to adopt new technologies out of their comfort zone, and the costs involved to implement and maintain these technologies (Martín-Gutiérrez et al., 2017). Furthermore, there is a difficulty in creating and deploying content (Yuen, Yaoyuneyong and Johnson, 2011). The point is not simply about using virtual environments to support education but how to produce effective instructional designs to integrate them so that the educational goals are achieved.

$\mathrm{Hu}-\mathrm{Au}$ and Lee (2017) present other challenges to adapt to new educational methods and environments: (i) reliance on traditional methods of knowledge transmission, such as lectures, which lead students to become disengaged; (ii) current learning contexts require factors difficult to reach or that are absent in traditional methods; and (iii) the need to acquire important skills up to the present time, such as systemic thinking, creativity and computational thinking, which are difficult to teach. It is difficult to change, but educators must review their education methods to stimulate students to develop the capacity to learn and a lifelong willingness to keep exploring new knowledge and modify learned expectations accordingly.

The application of technologies that reproduce virtual environments implies different levels of interaction and immersion in the educational context (Martín-Gutiérrez et al., 2017). It can assist in several positive aspects in building learning, increasing the understanding of the content addressed, the chance of retention of content in memory, the performance of physical tasks, collaboration, motivation, creativity, critical thinking, satisfaction, enthusiasm, among others (Papanastasiou et al., 2018; Radu, 2014; Resnyansky, Ibili and Billinghurst, 2019). The results presented in this systematic review corroborate the potential of virtual environments to positively support the learning process in Computer Science. On the other hand, there is still a long way to smoothly integrate them, as other new technologies, in an effective instructional design.

\section{Conclusion}

This paper carried out a systematic literature review aiming to investigate the contribution of the employment of AR, VR and MR technologies in the Computer Science learning process.

This research identified that no previous study has analyzed, in a systematic manner, how such technologies were utilized for teaching Computer Science subjects. Hence, after analyzing the 14 selected studies, and extracted information about the applied instructional strategies, as along as, covered subjects, technology, application type, tools, and visual resources, we can state that the main contribution of this research is the knowledge about the current scenario of this educational area in Computer Science. 
Another result of this research is the set of good practices presented, that may be explored and adopted by instructors when teaching the same subject as addressed by any of these studies. Yet, future studies aiming to adopt AR, VR, or MR technologies for teaching another compute science subject, may be based on the set of good practices for instructional design. Future studies may also investigate if the adoption of AR, VR, and MR can increase the motivation of students to learn Computer Science, as well, what is its impact on their learning effectiveness. Moreover, in the long run we also can investigate the impact of this approach on the students' dropout rate.

\section{Acknowledgments}

This study was financed in part by the Coordenação de Aperfeiçoamento de Pessoal de Nível Superior - Brasil (CAPES) - Finance Code 001.

\section{References}

Akdeniz, C. (2016). Instructional process and concepts in theory and practice. Improving the Teaching Process, 1, XXVII, 573.

Alhazbi, S. (2015). ARCS-based tactics to improve students' motivation in computer programming course. In: 10th International Conference on Computer Science and Education, ICCSE 2015, n. Iccse, 317-321.

Alptekin, M., Temmen, K. (2018). Reality based virtual preparation laboratory training. In: 2018 IEEE Global Engineering Education Conference (EDUCON), 963-968.

Ashfaq, Q., Sirshar, M. (2018). Emerging trends in augmented reality games | Jisc. In: 2018 International Conference on Computing, Mathematics and Engineering Technologies - iCoMET 2018.

Aveleyra, E.E., Racero, D.A., Toba, G.G. (2018). The didactic potential of AR in teaching physics. In: EDUNINE 2018 - 2nd IEEE World Engineering Education Conference: The Role of Professional Associations in Contemporaneous Engineer Careers, Proceedings, 1-3.

Azuma, R. (1997). A Survey of Augmented Reality. Teleoperators and Virtual Environments, 6, $355-385$.

Azuma, R., Baillot, Y., Behringer, R., Feiner, S., Julier, S., MacIntyre, B. (2001). Recent Advances of Augmented Reality. IEEE Computer Graphics and Applications, 21(6), Nov.-Dec, 34-47.

Brereton P., Kitchenham, B. A., Budgen, D., Turner, M., Khalil, M. (2007). Lessons from applying the systematic literature review process within the software engineering domain. Journal of Systems and Software, 80(4), 571-583.

Bujdoso, G., Novac, O.C., Szimkovics, T. (2017). Developing cognitive processes for improving inventive thinking in system development using a collaborative virtual reality system. In: 8th IEEE International Conference on Cognitive Infocommunications, CogInfoCom 2017 - Proceedings, 2018-Janua (CogInfoCom), 79-84.

Chandramouli, M., Zahraee, M., Winer, C. (2014). A fun-learning approach to programming: An adaptive Virtual Reality (VR) platform to teach programming to engineering). students. In: IEEE International Conference on Electro Information Technology, 581-586.

Chen, F., Lin, Y.C., Chien, J.W., Tsai, C.E. (2017a). Virtual reality for digital user experience and interactive learning based on user satisfaction: A pilot study. In: Proceedings - 2016 International Conference on Computational Science and Computational Intelligence, CSCI 2016, 1, 374-377.

Chen, J.Y., Liu, C.H., Hsieh, C.H. Huang, S.Y, Wang, W.K, Nien, B.H. (2017b). Kinect augmented reality gear game design. In: Proceedings of the 2017 IEEE International Conference on Applied System Innovation: Applied System Innovation for Modern Technology, ICASI 2017, 373-375. 
Christou, C. (2010). Using virtual reality in education. In: Tzanavari, A.; Tsapatsoulis, N. (Eds.). Affective, Interactive and Cognitive Methods for E-Learning Design: Creating an Optimal Education Experience. 1. ed. Nicosia: IGI Global, 228-243.

Dass, N., Kim, J., Ford, S., Agarwal, S., Chau, D.H. (2018). Augmenting coding: Augmented reality for learning programming. In: Proceedings of the Sixth International Symposium of Chinese CHI, 156-159.

Fachinetto, M. (2013). A realidade aumentada como suporte ao e-commerce. Universidade de Caxias do Sul, 74.

Fernandez, M. (2017). Augmented-virtual reality: How to improve education systems. Higher Learning Research Communications, 7(1), 1.

Ferrer, V., Perdomo, A., Rashed-Ali, H., Fies, C., Quarles, J. (2013). How does usability impact motivation in augmented reality serious games for education? In: 2013 5th International Conference on Games and Virtual Worlds for Serious Applications, VS-GAMES 2013, figure 1.

Fields, G., Corning, W., Lee, V., Xia, L., Maes, P. (2017). Technology and applications for collaborative learning in virtual reality then and now: Positioning a new wave of research on VR and learning, $C S C L$ $2017,719-726$.

Girvan, C. (2018). What is a virtual world? Definition and classification. Education Tech Research Dev 66, 1087-1100.

Greenwald, S.W., Kulik, A., Kunert, A., Beck, S., Fröhlich, B., Cobb, S., Parsons, S., Newbutt, N., Gouveia, C., Cook, C., Snyder, A., Payne, S., Holland, J., Buessing, S.,

Grivokostopoulou, F., Perikos, I., Hatzilygeroudis, I. (2016). An Innovative Educational Environment Based on Virtual Reality and Gamification for Learning Search Algorithms. In: Proceedings - IEEE 8th International Conference on Technology for Education, T4E 2016, 110-115.

Hönig, W., Milanes, C., Scaria, L., Phan, T., Bolas, M., Ayanian, N. (2015). Mixed reality for robotics. In: IEEE International Conference on Intelligent Robots and Systems, v. 2015- Decem, 5382-5387.

Hsu, C.Y., Chen, M.W., Wu, C.C. (2015). Teaching high school computer science with videos of historical figures - An augmented reality approach. In: Proceedings - 2015 International Conference on Learning and Teaching in Computing and Engineering, LaTiCE 2015, 22-25.

$\mathrm{Hu}-\mathrm{Au}, \mathrm{E}$., Lee, J.J. (2017). Virtual reality in education: A tool for learning in the experience age. International Journal of Innovation in Education, 4(4), 215-226.

Huang, Y., Ali, S., Zhai, X., Liu, R. (2017). Design and implementation of traditional Chinese medicine education visualization platform based on virtual reality technology. In: Proceedings - 2016 8th International Conference on Information Technology in Medicine and Education, ITME 2016, 499-502.

Kesim, M., Ozarslan, Y. (2012). Augmented reality in education: Current technologies and the potential for education. In: Procedia - Social and Behavioral Sciences, 47(December), 297-302.

Kirner, C., Siscoutto, R. (2007). Realidade virtual e aumentada: Conceitos, projeto e aplicações. In: Proc. IX Symposium on Virtual and Augmented Reality.

Kiryakova, G., Angelova, N., Yordanova, L. (2018). The potential of augmented reality to transform education into smart education, EBSCOhost. TEM Journal, 7(3). 556-565.

Li, F., Li, D., Zheng, J., Zhao, S. (2015). Virtual experiments for introduction of computing: Using virtual reality technology. In: Proceedings - Frontiers in Education Conference, FIE, 2014, 1-5.

Ma, J.Y., Choi, J.S. (2007). The virtuality and reality of Augmented reality. Journal of Multimedia, 2(1), 32-37.

Martín-Gutiérrez J., Fabiani, P., Benesova, W., Dolores, M., Mora, C. (2015). Augmented reality to promote collaborative and autonomous learning in higher education. Computers in Human Behavior, 51, $752-761$.

Martín-Gutiérrez, J., Mora, C.E., Añorbe-Díaz, B., González-Marrero, A. (2017). Virtual technologies trends in education. Eurasia Journal of Mathematics, Science and Technology Education, 13(2), 469-486.

Mesía, N.S., Sanz, C., Gorga, G. (2016). Augmented reality for programming teaching. Student satisfaction analysis. In: Proceedings - 2016 International Conference on Collaboration Technologies and Systems, CTS 2016, 165-171.

Milgram, P., Kishino, F. (1994). A taxonomy of mixed reality visual displays. IEICE Transactions on Information Systems, E77-D(12), 1-15. 
Nicola, S., Stoicu-tivadar, L., Patrascoiu, A. (2018). VR for education in information and tehnology: Application for bubble sort. In: 2018 13th International Symposium on Electronics and Telecommunications, ISETC 2018 - Conference Proceedings, Figure 2, 1-4.

Oberhauser, R., Lecon, C. (2017). Virtual reality flythrough of program code structures. In: VRIC '17 Proceedings of the Virtual Reality International Conference - Laval Virtual 2017, 1-4.

Papanastasiou, G., Drigas, A., Skianis, C., Lytras, M., Papanastasiou, E. (2018). Virtual and augmented reality effects on K-12, higher and tertiary education students' twenty-first century skills. Virtual Reality, 23, 425-436.

Pereira, A.S., Piovesan, S.D. (2010). Software in distance education: An application using virtual reality. In: 2010 IEEE International Conference on Intelligent Computing and Intelligent Systems, 548-551.

Qamari, C.N., Ridwan, M.R. (2018). Implementation of Android-based augmented reality as learning and teaching media of dicotyledonous plants learning materials in biology subject. In: Proceeding - $20173 r d$ International Conference on Science in Information Technology: Theory and Application of IT for Education, Industry and Society in Big Data Era, ICSITech 2017, 2018- January, 441-446.

Radu, I. (2014). Augmented reality in education: A meta-review and cross-media analysis. Personal and Ubiquitous Computing, 18(6), 1533-1543.

Radu, I., Mccarthy, B., Kao, Y. (2016). Discovering educational augmented reality math applications by prototyping with elementary-school teachers. In: Proceedings - IEEE Virtual Reality, 2016- July, 271-272.

Resnyansky, D., Ibili, E., Billinghurst, M. (2019). The potential of augmented reality for computer science education. In: Proceedings of 2018 IEEE International Conference on Teaching, Assessment, and Learning for Engineering, TALE 2018, December, 350-356.

Serafin, S., Adjourlu, A., Nilsson, N., Thomsen, L., Nordahl, R. (2017). Considerations on the use of virtual and augmented reality technologies in music education. In: 2017 IEEE Virtual Reality Workshop on K-12 Embodied Learning through Virtual and Augmented Reality, KELVAR 2017, 5-8.

Sherman, W.R., Craig, A.B. (2003). Understanding Virtual Reality-Interface, Application, and Design. 1, $12,608$.

Mello Sobrinho, E. (2011). Ambientes Virtuais Imersivos: A perspectiva de pesquisadores em relação à linguagem e à tecnologia. Programa Interdisciplinar de Linguística Aplicada, Faculdade de Letras, Universidade Federal do Rio de Janeiro. Rio de Janeiro, 169.

Sottilare, R., Defalco, J., Connor, J. (2014). Chapter 2 - A Guide to Instructional Techniques, Strategies and Tactics to Manage Learner Affect, Engagement, and Grit. Design Recommendation for Intelligent Tutoring Systems, July, 7-34.

Steuer, J. (1992). Defining virtual reality: Characteristics determining telepresence. Journal of Communication, 42(4), 73-94.

Stigall, J., Sharma, S. (2017). Virtual reality instructional modules for introductory programming courses. In: ISEC 2017 - Proceedings of the 7th IEEE Integrated STEM Education Conference, 00(c), 34-42.

Teng, C.H., Chen, J.Y. (2012). An augmented reality environment for learning OpenGL Programming. In: 2012 9th International Conference on Ubiquitous Intelligence and Computing and 9th International Conference on Autonomic and Trusted Computing, 996-1001.

Teng, C.H., Chen, J.Y., Chen, Z.H. (2018). Impact of augmented reality on programming language learning: Efficiency and perception. Journal of Educational Computing Research, 56(2), 254-271.

Vincur, J., Konopka, M., Tvarozek, J., Hoang, M., Navrat, P. (2017). Cubely: Virtual reality block-based programming environment. In: Proceedings of the 23rd ACM Symposium on Virtual Reality Software and Technology, (2), 84.

Visoottiviseth, V., Phungphat, A., Puttawong, N., Chantaraumporn, P., Haga, J. (2018). Lord of secure: The virtual reality game for Educating Network security. In: Proceeding of 2018 th ICT International Student Project Conference, ICT-ISPC 2018, 1-6.

Xiong, Z., Zhi, L., Jiang, J. (2018). The research of developing virtual jewelry worn system based on ar toolkit. In: 13th International Conference on Computer Science and Education, ICCSE 2018, (Iccse), 496-498.

Yang, K.J., Chu, H.C., Yang, K.H. (2016). Using the Augmented Reality Technique to Develop Visualization Mindtools for Chemical Inquiry-Based Activities. In: Proceedings - 2015 IIAI 4th International Congress on Advanced Applied Informatics, IIAI-AAI 2015, 354-357.

Yuen, S.C.Y., Yaoyuneyong, G., Johnson, E. (2011). Augmented reality: An overview and five directions for AR in education. Journal of Educational Technology Development and Exchange, 4(1), 119-140. 
A. Fernando Batista is a Computer Science Bachelor graduated from University of Vale do Itajaí (UNIVALI), Brazil, since 2017. Currently, he is a master student at the same university, working mainly in development methods with Augmented Reality technology applied on education. Complete CV: http: //lattes . cnpq. br/5227421596129980

M. Thiry has been working as a professor at University of Vale do Itajaí (UNIVALI), Brazil, since 1993, where he coordinates the Software Quality and Productivity Laboratory (LQPS), teaching and advising in both undergraduate (Computer Science) and graduate courses (Master in Applied Computer Science). He has large experience in education, research and development in Computer Science, focusing on Software Engineering and Informatics on Education, acting mainly in the following topics: requirements engineering, software process improvement, process modeling, software development methods and educational games.

R. Queiroz Gonçalves Computer Scientist conducted researches on areas related to Software Engineering, including Software Project Management and Requirements Is $\mathrm{PhD}$ (2017) and Master (2012) in Computer Science granted by Federal University of Santa Catarina (UFSC), with researches focused in project management, and software support tools. Is Computer Science Bachelor graduated by UNIVALI (2010). Since 2010 works as professor, lecturing on undergraduate and graduate programs, working on courses related to system development, system security, and non-relational databases.

A. Fernandes has been working as a professor at University of Vale do Itajaí (UNIVALI), Brazil, since 1998, where she coordinates the Applied Intelligence Laboratory (LIA), teaching and advising in both undergraduate (Computer Science) and graduate courses (Master in Applied Computer Science). She has large experience in education, research and development in Computer Science, focusing on Applied Intelligence and Informatics on Education, acting mainly in the following topics: artificial intelligence, data science and educational games. 
